\title{
Prevalence of hyperuricemia in cerebrovascular accidents and its correlation with their outcome
}

\author{
Kori P. ${ }^{1}$, Chouhan M. ${ }^{2}$, Singh Mandloi S. ${ }^{3 *}$ \\ DOI: https://doi.org/10.17511/ijmrr.2021.i04.10 \\ 1 Preeti Kori, Assistant Professor, Department of Medicine, Government Medical college, Ratlam, Madhya Pradesh, India. \\ 2 Mahendra Chouhan, Associate Professor, Department of Medicine, Government Medical college, Ratlam, Madhya Pradesh, India. \\ 3* Sohan Singh Mandloi, Assistant Professor, Department of Medicine, Government Medical college, Ratlam, Madhya Pradesh, India.
}

Introduction: Cerebrovascular accident or stroke is a disease of the vascular system of the brain. According to ICD 11, stroke is classified as a neurological disease and not under the circulatory system. It is the second leading cause of death worldwide. It cannot be said that high Serum Uric Acid [SUA] amongst patients with cerebrovascular accidents is directly correlated with their outcome. The present study planned to estimate uric acid levels and their association in acute stroke patients, both ischemic and hemorrhagic. Method: A total of 100 stroke patients admitted under the neurology department were included in the study. Brain imaging (CT/MRI) was performed. The serum uric acid was estimated. Results: Out of a total of 100 patients, 74 were males, and 26 were females. Nine patients were less than 45 years old and 91 patients were 45 and above. Thirty-nine patients had ischemic, and 61 patients had a hemorrhagic stroke, respectively. Out of 100 patients, 23 patients had normal uric acid levels $(<7 \mathrm{mg} / \mathrm{dl})$. Seventy-seven patients were with high uric acid levels. The mean serum uric acid concentration in male patients was $8.48 \pm 2.7$ and $9.20 \pm 2.7$ in females. Among the total 100 cases, 69 survived, and the remaining 31 were among the nonsurvivor group at the time of discharge. Mean serum uric acid in stroke survivors was $8.5 \pm 2.6$ $\mathrm{mg} / \mathrm{dl}$, while in non-survivors, it was $8.6 \pm 2.2 \mathrm{mg} / \mathrm{dl}$. There was no significant difference between the levels of uric acid among survivors and non-survivors. Conclusions: The prevalence of hyperuricemia $(>9 \mathrm{mg} / \mathrm{dl}$ ) amongst stroke patients was $77 \%$ in the present study. The values of serum uric acid were significantly elevated in the patients aged $>45$ years. The serum uric acid values were high among the group of hyperglycemic and hypertensive patients at the time of admission. There was no significant difference between the levels of uric acid among survivors and non-survivors.

Keywords: Serum uric acid, Ischemic Stroke, Hemorrhagic Stroke

Corresponding Author

Sohan Singh Mandloi, Assistant Professor, Department of Medicine, Government Medical college, Ratlam, Madhya Pradesh, India.

Email: drsohans@gmail.com
How to Cite this Article

Preeti Kori, Mahendra Chouhan, Sohan Singh Mandloi, Prevalence of hyperuricemia in cerebrovascular accidents and its correlation with their outcome. Int J Med Res Rev. 2021;9(4):269273.

Available From

https://ijmrr.medresearch.in/index.php/ijmrr/article/ view/1322
To Browse

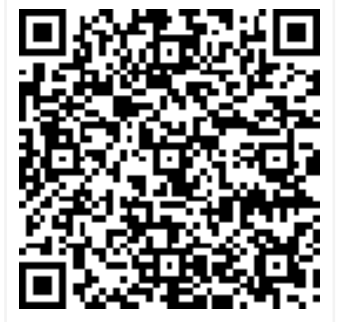

Manuscript Received 2021-06-24

Conflict of Interest No
Review Round 1 2021-07-04

Funding Nil

Review Round 2
2021-07-18
$\begin{gathered}\text { Ethical Approval } \\ \text { Yes }\end{gathered}$

Review Round 3 2021-07-29

Plagiarism $X$-checker $9 \%$
Accepted 2021-08-30

Note

(C) 2021 by Preeti Kori, Mahendra Chouhan, Sohan Singh Mandloi and Published by Siddharth Health Research and Social Welfare Society. This is an Open Access article licensed under a Creative Commons Attribution 4.0 International License https://creativecommons.org/licenses/by/4.0/ unported [CC BY 4.0]. 


\section{Introduction}

A cerebrovascular accident has also termed a stroke. Stroke is a disease of the vascular system of the brain. It is the second leading cause of death worldwide, causing 6.2 million deaths in 2011 [1-3]. Several population-based surveys on stroke were conducted from different parts of India. The ratio of cerebral infarct to haemorrhage was 2.21 . Hypertension was the most important risk factor. Stroke represented $1.2 \%$ of total deaths in India. Various risk factors have been implicated in the pathogenesis of CVA, divided into mainly two types, non-modifiable risk factors such as Age, Gender, Race. And modifiable risk factors (e.g.hypertension, carotid bruit/stenosis, cardiac disease, diabetes, dyslipidemia, tobacco, alcohol consumption, obesity).[1-3].

Cerebrovascular accidents are classified into two main types: Ischaemic Stroke and cerebral haemorrhage. Brain ischemia results from the occlusion of cervicobrachial vessels or hypoperfusion caused by various processes as atherothrombosis, embolism, or hemodynamic abnormalities5. In cerebral haemorrhage, there is rupture of a brain vessel causing leakage of blood into the brain parenchyma, cerebrospinal fluid (CSF) spaces around the brain, or both. There are two subcategories of spontaneous intracranial hemorrhages. Intracerebral haemorrhage $(\mathrm{ICH})$ is bleeding in the brain parenchyma itself, and subarachnoid hemorrhage $(\mathrm{SAH})$ refers to bleeding around the brain into the subarachnoid spaces and CSF. $[4,5]$.

\section{Material and method}

Setting Duration and type of study: The study was conducted on 100 patients of a Cerebrovascular accident admitted in the neurology unit of the Department of medicine, G R Medical College, Gwalior, over one year from November 2009 to October 2010 after obtaining Institutional Ethical Committee approval.

Study Design: Longitudinal Study

\section{Inclusion Criteria:}

01 . Age $>18$ years of age

02. History of sudden onset neurological deficit with brain imaging showing: Focal/global ischemia or Intracerebral haemorrhage

\section{Exclusion Criteria:}

01 . Age $<18$ years

02. Patient with a bleeding disorder or on anticoagulants.

03. Renal insufficiency, polycystic kidney disease.

Data collection procedure: After obtaining informed consent from the study participants, data were collected in pre-designed proforma regarding the patient's demography, medical history, and risk factors for stroke or vascular disease. Sample for serum uric acid and other biochemical parameters were taken within 24-48 hours of admission. Within the same period of access (24 to 48 hours), brain imaging (CT/MRI) was performed on the patients.

Statistical Analysis: Patients with serum uric acid level $>7 \mathrm{mg} / \mathrm{dl}$ were labelled as hyperuricemia. The results so obtained were subjected to the student's t-test and chi-square test for statistical analysis.

\section{Result}

The stroke patients were distributed into two categories based on mortality at the time of discharge. Out of the total 100 stroke cases, $69 \%$ of them survived. The mean value of uric acid among the survivor and non-survivor groups were $8.5 \pm$ 2.6 (range being $1.1-10.2$ ) and $8.6 \pm 2.2$ (range being $9.5-15)$, respectively. Out of 39 patients with ischaemic strokes, $16(41.02 \%)$ had hyperuricemia, and $23(58.98 \%)$ had normal uric acid levels. Out of 39 patients with ischaemic strokes, 8 (20.51\%) expired, and none had elevated serum uric acid levels. Amongst 61 patients with hemorrhagic stroke, all had elevated serum uric acid levels of more than $7 \mathrm{mg} / \mathrm{dl}$ (hyperuricemia). Out of 61 patients, 23(37.7\%) expired.

Demographic profile of CVA patients Among 100 patients in the present study, males were $74 \%$, and females were $26 \%$. Chart 1 Distribution of the CVA patients according to sex $(\underline{n=100})$.

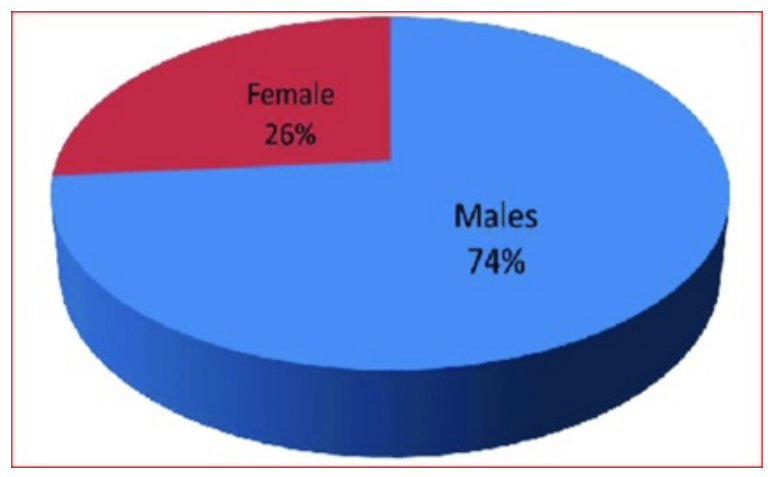


As shown in chart $2,91 \%$ of the patients were in the age group of $>45$, whereas $9 \%$ were young stroke (i.e. < 45-year-old). Chart 2 Distribution of the CVA patients according to age $(\underline{n=100})$ :

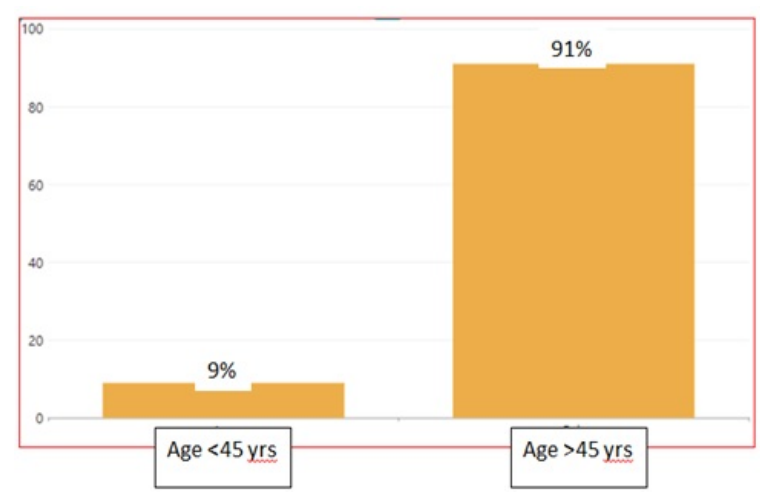

Table 1: comparison of uric acid levels based on age

\begin{tabular}{|l|l|l|}
\hline \multicolumn{1}{|c|}{ Age } & \multicolumn{1}{c|}{$<\mathbf{4 5}$ years $(\mathrm{n}=\mathbf{9})$} & \multicolumn{1}{c|}{$\mathbf{4 5}$ years $(\mathrm{n}=\mathbf{9 1})$} \\
\hline Mean uric acid + S.D & $6.49+3.1$ & $8.87+2.6$ \\
\hline Median (Range) & $8.5(1.1-8.6)$ & $9.1(3.3-15)$ \\
\hline
\end{tabular}

Table no. 1 shows, the mean uric acid level in the age group of $<45$ years was $6.49 \pm 3.1 \mathrm{mg} / \mathrm{dl}$, and the age group of $>45$ years was $8.87 \pm 2.6 \mathrm{mg} / \mathrm{dl}$. This is statistically significant. These factors though showing statistical significance, cannot be used for the general population because as age increases, the mean blood pressure also increases, and the lack of age sex-matched group hinders in generalising the findings obtained and thus concluding that age and sex are independent risk factors on their own in cases of CVA.

Table 2: Demographic profile of CVA patients at diagnosis

\begin{tabular}{|l|l|l|}
\hline \multicolumn{1}{|c|}{ Variables } & \multicolumn{1}{|c|}{ Mean + S.D } & \multicolumn{1}{|c|}{ Median(Range) } \\
\hline AGE(years) & $63+29.1$ & $65(35-90)$ \\
\hline MAP $(\mathrm{mmHg})$ & $119.9+19.5$ & $116.6(83.3-190)$ \\
\hline RBS $(\mathrm{mg} / \mathrm{dl})$ & $145+72.1$ & $112(50-356)$ \\
\hline Serum URIC ACID(mg/dl) & $8.6+2.7$ & $8.9(1.1-15)$ \\
\hline Se.Cholesterol $(\mathrm{mg} / \mathrm{dl})$ & $191+38.7$ & $195(97-319)$ \\
\hline Se.HDL $(\mathrm{mg} / \mathrm{dl})$ & $49.6+7.3$ & $50(20-66)$ \\
\hline Se.LDL $(\mathrm{mg} / \mathrm{dl})$ & $112.3+30.7$ & $118(11-196)$ \\
\hline Se.TGL $(\mathrm{mg} / \mathrm{dl})$ & $134+45.8$ & $124(66-295)$ \\
\hline
\end{tabular}

Table No. 2 shows, the mean MAP at the time of presentation was $119.9 \pm 19.5 \mathrm{mmHg}$, and the range was $(83.3$ - $190 \mathrm{mmHg})$, and the mean random blood sugar levels were $145+72 \mathrm{mg} / \mathrm{dl}$ and the range was (50- 356). The mean serum uric acid levels were $8.6 \pm 2.7 \mathrm{mg} / \mathrm{dl}$, with the range being (1.1 - 15). Serum cholesterol levels were $191 \pm$
$38.7 \mathrm{mg} / \mathrm{dl}$, and the range was (97-319). Mean HDL was $49.6 \pm 7.3(20-66)$, LDL was $112.3 \pm 30.7(11-$ 196), and TGL was $134 \pm 45.8$ (66-295), respectively. The mean $\mathrm{Hb}$ level was $10.8 \mathrm{gm} / \mathrm{dl}$ with a range from 4.1 to $14.9 \mathrm{gm} / \mathrm{dl}$.

Table No 3: Uric acid levels compared between ischemic and haemorrhagic stroke

\begin{tabular}{|c|l|l|}
\hline $\begin{array}{c}\text { Serum Uric } \\
\text { Acid }\end{array}$ & $\begin{array}{c}\text { Ischemic Stroke ( } \\
\mathbf{= 3 9})\end{array}$ & $\begin{array}{r}\text { Hemorrhagic Stroke ( } \mathbf{N}= \\
\mathbf{6 1})\end{array}$ \\
\hline Mean + S.D & $8.7+2.4$ & $8.6+2.7$ \\
\hline
\end{tabular}

Above table No. 3 shows the comparison between the mean serum uric acid levels between ischemic and hemorrhagic stroke. It did not show much of a difference when compared between the ischemic and hemorrhagic stroke groups. On applying the test of significance, no statistically significant value was seen.

Table 4: Showing uric acid levels compared b/w stroke survivors and non-survivors

\begin{tabular}{|l|l|l|}
\hline \multicolumn{1}{|c|}{$\begin{array}{c}\text { Serum Uric } \\
\text { Acid }\end{array}$} & \multicolumn{1}{|c|}{$\begin{array}{c}\text { Stroke Survivors } \\
(\mathbf{N = 6 9 )}\end{array}$} & \multicolumn{1}{|c|}{$\begin{array}{c}\text { Stroke Non-Survivors ( } \\
\mathbf{N}=31)\end{array}$} \\
\hline Mean + S.D & $8.5+2.6$ & $8.6+2.2$ \\
\hline Median & 8.6 & 11.1 \\
\hline Range & $1.1-10.2$ & $9.5-15$ \\
\hline
\end{tabular}

\section{Discussion}

Type of cv stroke: In the present study, 39\%of patients had an ischemic stroke, and $61 \%$ had a hemorrhagic stroke. This is contrary to the studies which have noted that the incidence of ischemic stroke is higher among their study groups. A survey by Wier et al., which included 3731 patients with stroke, showed that ischemic stroke contributed to $90 \%$ of the total cases studied. Similarly, in the CHS participants, approximately $87 \%$ had experienced ischemic stroke. Several other studies also quote that the incidence of ischemic stroke being higher than haemorrhagic stroke [6-10].

The majority of our patients had a haemorrhagic stroke, contrary to other studies. This can be explained, as the present study conducted in a tertiary centre, there may be reference bias, as ischemic stroke is generally managed in secondary heath centre and haemorrhagic stroke is more alarming and symptomatic than is usually referred to a tertiary centre.

The uric acid levels were elevated more in the nonsurvivor group, and statistical significance was not seen when the mean values were compared. 
Verdecchia et al. and colleagues found that serum uric acid was a powerful predictor of $\mathrm{CV}$ disease and all-cause mortality. Serum uric acid measured within the first 24 hours after hospital admission for acute stroke is an independent marker of poor outcome and can predict future vascular events. Uric acid levels independently predict bad outcomes as defined by death or survival in care (Indicating a poorer functional outcome) at 90 days after the index stroke.

Multiple studies provide strong evidence that elevated uric acid may also bear independent risk factors associated with total and CV mortality. Also, provide strong evidence that an elevated uric acid is dangerous rather than protective in subjects with acute stroke [13]. In the study by Loana Moaza et al., significantly higher serum uric acid values were found in stroke patients who died $(9.5 \pm 3 \mathrm{mg} / \mathrm{dl})$ than patients who survived $(6.9 \pm 4 \mathrm{mg} / \mathrm{dl})$ stroke. $[6,12,13]$.

Gender distribution of cases among ischemic and haemorrhagic Stroke: Out of the 39 cases of ischemic stroke, the majority were male, i.e. 29 $(74.35 \%)$ cases were male. And out of the 61 cases of haemorrhagic stroke, $45(73.77 \%)$ were males. In a study by Chamorro, among the number of patients admitted with ischemic stroke, the males outnumbered females. A similar pattern was observed in the present study in cases of ischemic stroke. Out of 100 patients, 23 patients had normal uric acid levels $(<7 \mathrm{mg} / \mathrm{dl})$. Seventy-seven patients were with elevated uric acid levels. So the prevalence of hyperuricemia ( $>7 \mathrm{mg} / \mathrm{dl}$ ) amongst stroke patients was $77 \%$ According to Mehrpour et al., the prevalence of hyperuricemia in stroke patients was $47.3 \%$. In another study by Rangavenamma et al., the prevalence of ischemic stroke was $25 \%$.[11,14,15].

\section{Conclusion}

The prevalence of hyperuricemia $(>7 \mathrm{mg} / \mathrm{dl})$ amongst stroke patients was $77 \%$ in the present study. The serum uric acid values were high among the group of hyperglycemic and hypertensive patients at the time of admission.

There was no significant difference between the levels of uric acid among survivors and nonsurvivors. Though most of the patients had hyperuricemia, it didn't correlate with inferior outcomes. Further study with a large sample size with a control group is required.

\section{This study adds to existing knowledge}

Though most patients had hyperuricemia, it didn't correlate with inferior outcomes. Age-wise distribution of uric acid was found statistically significant. As age advances, uric acid also rises.

\section{Contribution by different authors}

First author: Preeti Kori Assistant Professor Department of Medicine, GMC Ratlam References and Discussion Second author: Mahendra Chouhan Associate Professor, Department of Medicine, GMC Ratlam Data collection and statistical analysis Third and Corresponding Author: $\mathrm{Dr}$ Sohan Singh Mandloi, Concept and data collection

\section{Reference}

01. Wade S, Smith, S Claiborne Johnston, J Donald Easton. Cerebrovascular diseases. Harrison's Principles of Internal medicine, 16th Edition. Volume II: Mac Graw Hill, 2005; 2372-2380. [Crossref] [PubMed][Google Scholar]

02. Banerjee, Tapas Kumar, and Shyamal Kumar Das. Epidemiology of Stroke in India. Neurology Asia. 11(2006):1-4. [Crossref][PubMed][Google Scholar]

03. Jose Biller and Besty B Love. Ischemic Cerebrovascular disease, Vascular diseases of the Nervous system, Walter G Bradley Robert B Daroff, Gerald M,Fenichel, Joseph Jankovic, Neurology in clinical practice. 4th Edition, Volume II: Butterworth Heinemann. 2004;1197-1200. [Crossref][PubMed] [Google Scholar]

04. Adams HP Jr, Bendixen BH, Kappelle LJ, Biller J, Love BB, Gordon DL, et al. Classification of subtype of acute ischemic stroke, Definitions for use in a multicenter clinical trial, TOAST, Trial of Org 10172 in Acute Stroke Treatment. Stroke. 1993 Jan;24(1):35-41. doi: 10.1161/01.str.24.1.35 [Crossref][PubMed][Google Scholar]

05. Chung C S, Whaley J, Kley N, Anderson K, Louis R Caplan. Neurovascular disorders, Christopher G Goetz. Textbook of clinical Neurology 2nd Edition: Saunders. (2003):991-1014. [Crossref][PubMed] [Google Scholar] 
06. Christopher J Weir, Scott W Muir, Matthew R Walters, Kennedy R Lees. FRCP- Predictor of Poor Outcome and Future Vascular Events After Acute. Stroke. 2003;34:1951. [Crossref][PubMed][Google Scholar]

07. Manolio TA, Kronmal RA, Burke GL, O'Leary DH, Price TR. Short-term predictors of incident stroke in older adults, The Cardiovascular Health Study. Stroke. 1996 Sep;27(9):1479-86. doi: 10.1161/01.str.27.9.1479 [Crossref][PubMed] [Google Scholar]

08. Bamford J, Sandercock P, Dennis M, Warlow C, Jones $L$, McPherson $K$, et al. A prospective study of acute cerebrovascular disease in the community: the Oxfordshire Community. Stroke Project. 198186. 1 [Crossref][PubMed][Google Scholar]

09. Jørgensen HS, Plesner AM, Hübbe $P$, Larsen $K$. Marked increase of stroke incidence in men between 1972 and 1990 in Frederiksberg, Denmark. Stroke. 1992 Dec;23(12):1701-4. doi: 10.1161/01.str.23.12.1701 [Crossref][PubMed] [Google Scholar]

10. Tell GS, Fried LP, Hermanson $B$, Manolio TA, Newman AB, Borhani NO. Recruitment of adults 65 years and older as participants in the Cardiovascular Health Study. Ann Epidemiol. 1993 Jul;3(4):358-66. doi: 10.1016/1047-2797(93)90062-9 [Crossref] [PubMed][Google Scholar]
11. Chamorro A, Obach V, Cervera A, Revilla M, Deulofeu $\mathrm{R}$, Aponte $\mathrm{JH}$. Prognostic significance of uric acid serum concentration in patients with acute ischemic stroke. Stroke. 2002 Apr;33(4):1048-52. doi: 10.1161/hs0402.105927 [Crossref][PubMed] [Google Scholar]

12. Verdecchia P, Schillaci G, Reboldi G, Santeusanio F, Porcellati C, Brunetti P. Relation between serum uric acid and risk of cardiovascular disease in essential hypertension, The PIUMA study. Hypertension. 2000 Dec;36(6):1072-8. doi: 10.1161/01.hyp.36.6.1072 [Crossref][PubMed] [Google Scholar]

13. Loana Mozoa, Camelia Chiulana, CorIna Goruna T. Costeaba Annals of West University of Timisoara Series of Chemistry. . 16(2)(2007)227 - 236. [Crossref][PubMed][Google Scholar]

14. Mehrpour M, Khuzan M, Najimi N, Motamed MR, Fereshtehnejad SM. Serum uric acid level in acute stroke patients. Med J Islam Repub Iran. 2012 May;26(2):66-72. Scholar]

[Crossref][PubMed][Google

15. Rangavenamma S, Goduguchintha Lepakshi, and Nagatham Padmaja. A Study of Serum Uric Acid Levels in Acute Ischemic Stroke Patients Admitted in Tertiary Care Hospital At Tirupati. stroke. 5:6. [Crossref][PubMed][Google Scholar] 